\title{
Best practices for disinfection of noncritical environmental surfaces and equipment in health care facilities: A bundle approach
}

\author{
William A. Rutala PhD, MPH ${ }^{\mathrm{a}, *}$, David J. Weber MD, MPH ${ }^{\mathrm{a}, \mathrm{b}}$ \\ ${ }^{a}$ Division of Infectious Diseases, University of North Carolina School of Medicine, Chapel Hill, NC \\ ${ }^{\mathrm{b}}$ Department of Hospital Epidemiology, University of North Carolina Hospitals, Chapel Hill, NC
}

Key Words:

Disinfection

Environment

Surfaces

Equipment

\begin{abstract}
Over the past decade, there is excellent evidence in the scientific literature that contaminated environmental surfaces and noncritical patient care items play an important role in the transmission of several key health care-associated pathogens including methicillin-resistant Staphylococcus aureus, vancomycin-resistant enterococci, Acinetobacter, norovirus, and Clostridium difficile. Thus, surface disinfection of noncritical environmental surfaces and medical devices is one of the infection prevention strategies to prevent pathogen transmission. This article will discuss a bundle approach to facilitate effective surface cleaning and disinfection in health care facilities. A bundle is a set of evidence-based practices, generally 3-5, that when performed collectively and reliably have been proven to improve patient outcomes. This bundle has 5 components and the science associated with each component will be addressed. These components are: creating evidencebased policies and procedures; selection of appropriate cleaning and disinfecting products; educating staff to include environmental services, patient equipment, and nursing; monitoring compliance (eg, thoroughness of cleaning, product use) with feedback (ie, just in time coaching); and implementing a "no touch" room decontamination technology and to ensure compliance for patients on contact and enteric precautions. This article will also discuss new technologies (eg, continuous room decontamination technology) that may enhance our infection prevention strategies in the future.
\end{abstract}

Over the past decade, there is excellent evidence in the scientific literature that contaminated environmental surfaces and noncritical patient care items play an important role in the transmission of several key health care-associated pathogens, including methicillin-resistant Staphylococcus aureus (MRSA), vancomycinresistant enterococci (VRE), Acinetobacter, norovirus, and Clostridium difficile. ${ }^{1-13}$ All of these pathogens have been demonstrated to persist in the environment for days (in some cases months), ${ }^{9,13-15}$ frequently contaminate the environmental surfaces in rooms of colonized or infected patients, ${ }^{16}$ transiently colonize the hands of health care personnel, ${ }^{17,18}$ can be transmitted by health care personnel, and cause outbreaks in which environmental transmission was deemed to play a role. Importantly, a study by Stiefel et $\mathrm{al}^{18}$ demonstrated that contact with the environment was just as likely to contaminate the hands of health care providers as was direct

\footnotetext{
* Address correspondence to William A. Rutala, PhD, MPH, CIC, Division of Infectious Diseases, University of North Carolina School of Medicine, Bioinformatics Building, CB\#7030, Chapel Hill, NC 27514-7030.

E-mail address: brutala@med.unc.edu (W.A. Rutala).

Conflicts of interest: Dr. Rutala is a consultant to PDI and on an advisory board for Kinnos. Dr. Weber is a consultant to PDI.
}

contact with the patient. Further, admission to a room in that the previous patient had been colonized or infected with MRSA, VRE, Acinetobacter, or $C$ difficile, has been shown to be a risk factor for the newly admitted patient to develop colonization or infection. ${ }^{19,20}$ Thus, surface disinfection of noncritical environmental surfaces and medical devices (defined as those that contact intact skin) is one of the important infection prevention strategies to prevent pathogen transmission.

This infection risk from environmental surfaces is not surprising as multiple studies have demonstrated that environmental surfaces and objects in rooms are frequently not properly cleaned and these surfaces may be important in transmission of health care-associated pathogens. $^{7}$ Further, although interventions aimed at improving cleaning thoroughness have demonstrated the effectiveness of surface disinfection in reducing microbial contamination and/or health care-associated infections (HAIs), ${ }^{10,11,21-27}$ many surfaces remain inadequately cleaned and, therefore, potentially contaminated. The purpose of this article is to review and update studies on surface disinfection $^{1,28,29}$ and use a best practices bundle created by Havill ${ }^{30}$ to facilitate effective surface cleaning and disinfection on noncritical items in health care facilities. 


\section{Noncritical Items}

Noncritical items are those that come in contact with intact skin but not mucous membranes. Intact skin acts as an effective barrier to most microorganisms; therefore, the sterility of items in contact with intact skin is "not critical." Examples of noncritical items are bedpans, blood pressure cuffs, crutches, bed rails, bedside tables, patient furniture, toys, ${ }^{31}$ portable equipment (eg, wheel chairs, infusion pumps, pulse oximeters, blood pressure cuffs, medication carts), ${ }^{8,32,33}$ and floors. $^{34,35}$ The 5 most commonly touched noncritical items in the patient environment have been quantitatively shown to be bed rails, bed surface, supply cart, overbed table, and intravenous (IV) pumps. ${ }^{36}$ In contrast to critical and some semicritical items, most noncritical reusable items may be decontaminated in which they are used and do not need to be transported to a central processing area. There is virtually no documented risk of transmitting infectious agents to patients via noncritical items ${ }^{37}$ when they are used as noncritical items and do not contact nonintact skin, mucous membranes, and/or sterile tissue. However, these noncritical environmental surfaces (eg, bedside tables, bed rails) could potentially contribute to secondary transmission by contaminating hands of health care providers or by contact with medical equipment that will subsequently come in contact with patients. ${ }^{2}$

Many Environmental Protection Agency (EPA)-registered liquid disinfectants have a 10-minute label claim. However, multiple investigators have demonstrated the effectiveness of these disinfectants against vegetative bacteria (eg, Listeria, Escherichia coli, Salmonella, VRE, MRSA), yeasts (eg, Candida), mycobacteria (eg, Mycobacterium tuberculosis), and viruses (eg, poliovirus) at exposure times of 30-60 seconds. ${ }^{38-44}$ Thus, it is acceptable from a microbial inactivation perspective to disinfect noncritical medical equipment (eg, blood pressure cuff) and noncritical surfaces (eg, bedside table) with an EPAregistered disinfectant or disinfectant/detergent at the proper usedilution and a contact time of $\geq 1$ minute. ${ }^{29,41,43-45}$ Considering that the typical drying time for a liquid disinfectant on a surface is 1-4 minutes, ${ }^{44} 1$ application of the germicide on all hand contact or touchable surfaces to be disinfected is recommended.

Current Topics (Mops, Wipes, Floors, Quat Absorption to Wipes, Biofilms, and Disinfectant Kill Time)

\section{Mops and Wipes}

Mops (microfiber and cotton-string), reusable cleaning cloths, disposable wipes, and sprays are regularly used to achieve low-level disinfection. ${ }^{28}$ Disinfectant cleaning wipes and sprays (eg, quaternary ammonium compounds [Quats] and alcohol, chlorine) have been found to be highly effective ( $>4-\log _{10}$ reduction) in removing/inactivating epidemiologically important pathogens. ${ }^{46-48}$ Hospital laundering practices may not be sufficient to remove microbial contaminants of reusable cleaning towels. ${ }^{49,50}$

Mops (especially cotton-string mops) are commonly not kept adequately cleaned and disinfected, and if the water-disinfectant mixture is not changed regularly (eg, after every 3-4 rooms, no longer than 60 minute intervals), the mopping procedure may actually spread heavy microbial contamination throughout the health care facility. ${ }^{51}$ In 1 study, standard laundering provided acceptable decontamination of heavily contaminated mopheads but chemical disinfection with a phenolic was less effective. ${ }^{51}$ The frequent laundering of cottonstring mops (eg, daily) is, therefore, recommended. Microfiber mops have demonstrated superior microbial removal compared to cotton string mops when used with detergent cleaner (ie, 95\% vs 68\%, respectively). Use of a disinfectant did significantly improve microbial removal when a cotton string mop was used when compared to the detergent cleaner (ie, $95 \%$ vs $68 \%$, respectively). ${ }^{52}$

\section{Quat Absorption to Wipes}

Several studies have demonstrated that the decreased activity of quaternary ammonium compounds via binding when exposed to cotton wipes, microfiber, and 1 of 2 disposable wipes. ${ }^{53-55}$ These evaluations demonstrated a significant reduction $(>50 \%)$ of quaternary ammonium compounds concentrations after exposure to the wipes/ towels. ${ }^{53-55}$ One study tested the disinfectant performance using a standardized test and the disinfectants passed when exposed to the microfiber towels and failed when exposed to the cotton towels. ${ }^{53}$ Although cotton and microfiber retain the quaternary ammonium compound, 1 unpublished study has shown they provide equivalent removal/inactivation of MRSA from a surface as nonwoven spunlace wipes (eg, 4.41- $\log _{10}$ reduction with cotton and Quat, 4.60- $\log _{10}$ reduction with spunlace, $4.51-\log _{10}$ reduction with microfiber, 4.40 $\log _{10}$ reduction with cellulose; Rutala, Gergen, Weber, unpublished results, 2013). The nonwoven spunlace wiper was prepared with a fiber content intended not to bind Quats. ${ }^{55}$ Manufacturers of disposable wipes believe they have addressed this issue as any absorption of the Quat that may occur has been taken into account because the wipes are tested via EPA-registration tests for active ingredient content from the expressed liquid. Additional investigations are necessary to ensure a minimum effective concentration is present to achieve the antimicrobial label claim.

\section{Floors}

Studies have recently evaluated hospital floors as a potential source of pathogen dissemination. Deshpande et $\mathrm{al}^{34}$ found floors in patient rooms were frequently contaminated with health care pathogens (eg, $C$ difficile, MRSA, VRE [contamination range was 35\%-53\% during the patient stay]), and high-touch objects (eg, blood pressure cuffs and call buttons) were often (41\%) in contact with the floor. Contact with objects on the floors resulted in transfer of pathogens to hands or gloves at varying frequencies (eg, C difficile 3\%, VRE 6\%, and MRSA $18 \%) .{ }^{34}$ Another study found that a nonpathogenic virus inoculated onto floors in hospital rooms disseminated rapidly to the footwear and hands of patients and to high-touch surfaces in the rooms. The virus was also frequently found on high-touch surfaces in adjacent rooms and nursing stations. This suggests that health care providers contributed to dissemination after acquiring the virus during contact with surfaces or patients. ${ }^{35}$ Although further studies are needed to determine if floors contribute to pathogen transfer, these data support the disinfection of floors.

\section{Biofilms}

Although biofilms are traditionally associated with wet environments such as indwelling medical devices, some data suggest that biofilms have also been identified on dry surfaces. ${ }^{56-58}$ In 1 multicenter study, 61 terminally cleaned items from 3 different United Kingdom hospitals, were investigated using culture-based methods and scanning electron microscopy. Multispecies dry biofilms were recovered from $95 \%$ of 61 samples. ${ }^{58}$ These dry biofilms were predominately formed by gram-positive bacteria. Biofilms are less susceptible to disinfectants but oxidizing agents are more effective. ${ }^{59,60}$ The role of dry biofilms in transmission via surfaces needs to be established as well as what germicidal products are effective against dry biofilms.

\section{Disinfectant Kill Time}

Each chemical disinfectant requires a specific length of time it must remain in contact with a microorganism to achieve complete inactivation. This is known as the "kill time" (or "contact time") and the registered kill times for each microorganism will be clearly listed on the label of EPA-registered liquid disinfectants. Fast kill times are important because they provide confidence there is complete killing of the most common health care-associated pathogens before the disinfecting solution dries or is removed, and before patients or staff 
are likely to re-touch the surface. For example, some disinfectants may have a kill time for vegetative bacteria of 1 minute, which means that the bacteria listed on its label will be inactivated within 1 minute. Other products, often-concentrated formulas that require dilution before use, are registered by the EPA for use against bacteria and viruses (eg, HBV, HIV) with a contact time of 10 minutes. Such a long contact time is not practical for disinfection of environmental surfaces in a health care setting because most health care facilities only apply a water-based disinfectant once and allow it to dry, which normally takes $1-4$ minutes. ${ }^{44}$

Although the Centers for Disease Control and Prevention guideline mentions the disinfectant user must follow all applicable label instructions on EPA-registered products, it discusses many scientific studies that have demonstrated the efficacy of hospital disinfectants against pathogens with a contact time of at least 1 minute. ${ }^{43}$ To our knowledge, there are only 2 articles in the peer-review literature that assessed EPA-registered disinfectants that are directly on point of this issue. One publication tested common health care disinfectants (such as Quat-alcohol, chlorine, phenolic) against $S$ aureus, E coli, Pseudomonas aeruginosa, and Salmonella choleraesuis at 30 seconds and 5 minutes and showed the maximum $\log _{10}$ reduction (ie, $\sim 5-\log _{10}$ reduction) was achieved in 30 seconds. ${ }^{41}$ Thus, this study showed the $\log _{10}$ reductions at 30 seconds was identical to the $\log _{10}$ reduction at 5 minutes. West et $\mathrm{al}^{44}$ corroborated this study and demonstrated that wet time is not crucial for disinfection as $\log _{10}$ reductions at 30 seconds were not significantly different than the $\log _{10}$ reductions at 60 minutes (ie, $\sim 4-\log _{10}$ reduction at both time points, 30 seconds and 60 minutes). Because the $\log _{10}$ reductions at 30 seconds and 60 minutes were nearly identical, there was no microbial reduction benefit for wet times $>30 \mathrm{sec}$ onds. ${ }^{44}$ This refutes the proposition that visual wetness is a proxy for determining effective disinfection ${ }^{61}$ and challenges the need for citations and punitive actions by accrediting agencies when a disinfectant does not stay wet for its registered contact time (eg, dries in 1 minute but registered contact time is 2 minutes). Clearly, wet times are important but there are no data that demonstrate that wet times beyond 1 minute improve microbial reduction and have an infection prevention benefit. The disinfectant should be applied wet enough to achieve sufficient wetness to ensure that a wet time of at least 1 minute is achieved. When the wipe is too dry to achieve the 1 minute wet time it should be replaced with a fresh wet wipe. At University of North Carolina Hospitals, we developed risk assessments, which justifies the use of hospital disinfectants and disinfectant wipes (eg, Quat-alcohol) with a wet time of 1 minute. ${ }^{62}$ This 1 minute wet time for noncritical environmental surfaces and noncritical medical devices is consistent with the review of the literature in the Centers for Disease Control and Prevention guideline as well as 2 studies directly on point to this issue. ${ }^{41,44}$

\section{A Bundle Approach}

The Institute for Healthcare Improvement developed the concept of bundles to assist health care providers to more reliably provide the best care for patients. A bundle is a set of evidence-based practices, generally $3-5$, that when performed collectively and reliably have been proven to improve patient outcomes. The "power" of a bundle comes from a body of science that supports it and execution of the components of the bundle with complete consistency. The science in the bundle are not new and are generally well established but they are not performed unfailingly. As stated by Dr. Carol Hara$\operatorname{den}^{63}$ of the Institute for Healthcare Improvement, a bundle ties the science-based interventions together into a package that providers know must be followed uniformly and completely for maximal patient benefit.

This bundle, identified by Havill ${ }^{30}$, has 5 components, which are creating policies and procedures; appropriate selection of cleaning and disinfecting products; educating staff to include environmental services (ES), patient equipment and nursing; monitoring compliance (eg, thoroughness of cleaning, product use) with feedback; and implement a "no touch" room decontamination technology and ensure compliance for patients on contact and enteric precautions. This article will briefly review these practices.

\section{Creating Policies and Procedures}

Environmental cleaning and disinfection are an integral part of preventing transmission of pathogens. Some science-based practices of a health care policy for cleaning and disinfection of noncritical ES and medical devices are defined in Table 1. One component of policy development is the standardization of cleaning/disinfecting of patient rooms and equipment throughout the hospital to ensure all surfaces are being cleaned and disinfected per institutional policy. At University of North Carolina Hospitals, the infection prevention staff found: some units using ES to clean and disinfect certain pieces of equipment (eg, Dinamap blood pressure monitor, IV pumps/poles, sequential compression device [SCD] pumps); some units used patient equipment; and some units used nursing staff (written communication, K. Schultz, 2017). This results in many problems to include ES staff must remember what their duties are in different patient care areas. This is especially true in which nurses or ES staff float to various care units such as during second and third shift. This was resolved through a multidisciplinary group that created a standardized plan for cleaning patient rooms and pieces of patient equipment through the hospital. The group decided the ES staff were responsible for cleaning and disinfecting Dinamaps, IV poles/pumps, and SCD pumps, whereas nursing staff were responsible for clearing out all linens, telemetry box with wires, and remove disposable items (eg, SCD sleeves, $\mathrm{O}_{2}$ probes, blood pressure cuffs) within 15 minutes of patient discharge. Normal nursing devices such as halter monitors, blood glucose meters, and portable pulse oximeters were assigned to the unit nursing staff to clean and disinfect (written communication, K. Schultz, 2019). Institutional policy must ensure all patient care equipment and surfaces are receiving appropriate cleaning and disinfection by assigning these responsibilities, ${ }^{64}$ ensuring adequate time to perform the service and auditing compliance.

\section{Table 1}

Science-based components of a health care policy for cleaning/disinfection of noncritical environmental services and medical devices

- Standardize cleaning/disinfection of patient rooms and noncritical medical devices throughout the hospital.

- An EPA-registered hospital disinfectant.

- All touchable, hand contact surfaces should be wiped daily, when spills occur, and when the surfaces are visible soiled.

- All noncritical medical devices should be disinfected daily and when soiled. The institutional protocol should include shared portable equipment such as wheelchairs, ECG machines, portable x-ray machines, glucometers, and blood pressure cuffs.

- Cleaning should be from the cleanest to the dirtiest areas (the bathroom will be cleaned last followed by the floor).

- Change cleaning cloths after every room and use at least 3 cloths per room; typically, 5-7 cloths.

- Damp mop floor with a disinfectant-detergent.

- If disinfectant is prepared on-site: document correct concentration as concentration delivered by automated disinfectant dispensers vary. ${ }^{54}$

- Address treatment time/contact time/kill time for wipes and liquid disinfectants (eg, treatment time for wipes is the kill time and includes a wet time via wiping as well as the undisturbed time).

- Cleaning/disinfecting staff must be trained on personal protective equipment and comply with the instruction.

$E C G$, electrocardiogram; EPA, Environmental Protection Agency. 
Table 2

Properties of an ideal disinfectant

1. Broad spectrum: should have a wide antimicrobial spectrum, including kill claims for the pathogens that are the common causes of HAIs and outbreaks.

2. Fast acting: should have a rapid kill and short kill/contact time listed on the label.

3. Remains wet: should keep surfaces wet long enough to meet listed kill/treatment time for wipes/sprays with a single application or meet wet-times recommended by evidence-based guidelines.

4. Not affected by environmental factors: should be active in the presence of organic matter (eg, blood, sputum, feces) and compatible with soaps, detergents, and other chemicals encountered in use.

5. Nontoxic: should not be irritating to the user, visitors, and patients. It should not induce allergic symptoms (especially asthma and dermatitis). The toxicity ratings for disinfectants are danger, warning, caution, and none.

6. Surface compatibility: should be proven compatible with common health care surfaces and equipment.

7. Persistence: should have sustained antimicrobial activity or residual antimicrobial effect on the treated surface.

8. Easy to use: should be available in multiple forms such as wipes (large and small), sprays, pull-tops, refills; directions for use should be simple and contain information about personal protective equipment as required.

9. Acceptable odor: should have an odor deemed acceptable by users and patients.

10. Economical: costs should not be prohibitively high but when considering costs of disinfectant should also consider product capabilities, cost per compliant use, etc.

11. Solubility: should be soluble in water.

12. Stability: should be stable in concentrate and use dilution.

13. Cleaner: should have good cleaning properties.

14. Nonflammable: should have flash point below $150^{\circ} \mathrm{F}$.

Modified from Molinari et $\mathrm{al}^{65}$ and Rutala and Weber ${ }^{29}$

HAIs, health care-associated infections.

\section{Selecting Cleaning and Disinfecting Products}

The 2 essential components for effective surface disinfections are the product and the practice. The perfect disinfectant, or product, for health care disinfection has not been introduced; however, there is a wide array of excellent disinfectants that offer a range of characteristics. Table 2 examines the properties of the ideal disinfectant and Table 3 reviews the advantages and disadvantages of the low-level disinfectants used for surface disinfection in health care facilities. ${ }^{29}$

The disinfectants used in health care facilities are 1-step products, that is, they clean and disinfectant in 1-step rather than requiring 2 independent steps (ie, cleaning, followed by disinfection). ${ }^{29}$ In general, no precleaning is necessary unless spill or gross contamination is present in which case cleaning precedes the use of a disinfectant. Disinfectants are intended for use on hard, nonporous surfaces; however, some products are EPA-registered for application to soft surfaces such as hospital privacy curtains. ${ }^{69}$ Hospitals should avoid the use of noncleanable surfaces such as fabric chairs in clinical areas and use a cleanable covering fabric (eg, vinyl). Organic matter interferes with the effectiveness of the disinfectant by altering the antimicrobial activity of the disinfectant or protecting the pathogen from exposure to the disinfectant. Device material (eg, polypropylene and ultra-high molecular weight polyurethane), cleaning agents, surface roughness, and the presence of blood test soil and bacteria all interact and affect the cleanability of reusable medical devices. ${ }^{48}$ In this article, we use the term "cleaning/disinfection" to reference this 1-step process for cleaning and disinfecting a noncritical item. ${ }^{29}$ "Cleaning" refers to the removal of surface debris (eg, dust, organic material), whereas "disinfection" refers to the use of a disinfectant or germicide designed to kill microorganisms. Cleaning/disinfection or environmental cleaning, which refers broadly to an organized process for cleaning, disinfecting, and monitoring, ${ }^{7,70}$ is a horizontal control measure. Horizontal controls are broad-based approaches to infection prevention as they attempt reduction to all infections owing to all pathogens and include hand hygiene, environmental control, and minimizing unnecessary use of invasive devices. ${ }^{71}$ Often cleaning is enhanced by detergents and surfactants. Surfactants enhance the cleaning efficacy of the disinfectant and ensure complete and even coverage of the surface, preventing beading that occurs with some liquids. ${ }^{29,72}$ It is important to achieve even and thorough coverage of a surface to result in even and complete disinfection. Multiple studies have shown $10 \%-50 \%$ of the surfaces in patient rooms colonized or infected with $C$ difficile, MRSA and VRE are contaminated with these pathogens and a lack of thoroughness of cleaning contaminated surfaces in patient rooms (mean $32 \%$ of objects cleaned) has been linked to an overall $120 \%$ increase risk of infection to the next occupant in that room. ${ }^{5,19,73}$

Although the process of selecting an optimal health care product or disinfectant used for low-level disinfection of noncritical items is commonplace in health care facilities, there are limited articles in the peer-reviewed literature on this topic. ${ }^{29}$ Studies support the use of disinfection rather than the use of a nongermicidal detergent on environmental surfaces in health care. ${ }^{10,74}$ One study showed that daily use of a disinfectant applied to environmental surfaces with a $80 \%$ compliance is superior to a nongermicidal detergent because it results in significantly reduced rates of HAIs caused by $C$ difficile, MRSA and VRE. ${ }^{75}$ Nongermicidal detergents are not recommended for multiple reasons, ${ }^{74}$ to include detergent wipes transfer significant amounts of epidemiologically important pathogens (eg, MRSA, $C$ difficile) over surfaces ${ }^{76}$ and disinfectants are more effective than detergents in reducing microbial contamination. ${ }^{47}$ Similarly, results have demonstrated efficient transfer of $C$ difficile spores from contaminated-to-clean surfaces by nonsporicidal wipes and overused sporicidal wipes. $^{77}$

\section{Educate Staff on Surface Disinfection Policies and Practices}

The other component of effective surface disinfection is the practice of thorough application such that the disinfectant contacts all hand-contact or touchable surfaces. It involves proper training of hospital staff (especially ES and nursing) and adherence to the manufacturer's label instructions (except in the cases in which an institution may prepare a formal risk assessment to follow alternate contact times such as a $\geq 1$ minute wet time). ${ }^{62}$ Several investigators have shown that educational interventions directed at ES, enhanced cleaning, and additional staff can result in improved decontamination of environmental surfaces. ${ }^{10,11,21-27}$ Other factors that affect practice and performance include: sufficient cleaning time; contact time; concentration; surface type; frequency of changing wipes; organic soil and hard water; and porosity of the surface. The combination of product and practice results in effective surface disinfection, including the reduction of patient risk via microbial removal and/or inactivation and improved patient outcomes. ${ }^{10,11,21-27,29}$ The criticality of practice is highlighted by studies that demonstrate surface contamination with epidemiologically important pathogens is owing to a failure to thoroughly clean and disinfect surfaces rather than a faulty product or procedure. $^{78}$

A curriculum should be developed for the training and education of cleaning and disinfecting personnel in health care facilities. This training should be provided at employment and on a regular basis (eg, daily huddles, weekly/monthly in-service training). The training should include: what items must be cleaned (eg, all hand contact items such as side rails, overbed table, television remote control); the type of cleaning (eg, isolation room, routine daily cleaning, discharge cleaning); order in which to clean the items (ie, cleanest to dirtiest [bathroom last followed by the floor]); the dilution of the EPA-registered disinfectant (if not ready-to-use or disposable wipe); appropriate test strip of the disinfectant if mixed on-site and the results documented; how many wipes per room; and why ES staff are valuable members of the infection prevention team. ${ }^{30,79}$ Sufficient time 
Table 3

Summary of advantages and disadvantages of disinfectants used as low-level disinfectants

\begin{tabular}{|c|c|c|}
\hline Disinfectant active & Advantages & Disadvantages \\
\hline Alcohol & $\begin{array}{l}\text { - Bactericidal, tuberculocidal, fungicidal, virucidal } \\
\text { - Fast acting } \\
\text { - Noncorrosive } \\
\text { - Nonstaining } \\
\text { - Used to disinfect small surfaces such as rubber stoppers on } \\
\text { medication vials } \\
\text { - No toxic residue }\end{array}$ & $\begin{array}{l}\text { - Not sporicidal } \\
\text { - Microbicidal activity affected by organic matter } \\
\text { - Slow acting against nonenveloped viruses (eg, norovirus) } \\
\text { - No detergent or cleaning properties } \\
\text { - Not EPA-registered } \\
\text { - Damage some instruments (eg, harden rubber, deteriorate glue) } \\
\text { - Flammable (large amounts require special storage) } \\
\text { - Evaporates rapidly making contact time compliance difficult } \\
\text { - Not recommended for use on large surfaces } \\
\text { - Outbreaks ascribed to contaminated alcohol }\end{array}$ \\
\hline $\begin{array}{l}\text { Sodium hypochlorite } \\
\text { (chlorine) }\end{array}$ & $\begin{array}{l}\text { - Bactericidal, tuberculocidal, fungicidal, virucidal } \\
\text { - Sporicidal (in high concentrations) } \\
\text { - Fast acting } \\
\text { - Inexpensive (in dilutable form) } \\
\text { - Nonflammable } \\
\text { - Unaffected by water hardness } \\
\text { - Reduces biofilms on surfaces } \\
\text { - Relatively stable (eg, 50\% reduction in chlorine concentration in } \\
30 \mathrm{~d})^{67} \\
\text { - Used as the disinfectant in water treatment } \\
\text { - EPA-registered }\end{array}$ & $\begin{array}{l}\text { - Reaction hazard with acids and ammonias } \\
\text { - Leaves salt residue } \\
\text { - Corrosive to metals (some ready-to-use products may be formulated } \\
\text { with corrosion inhibitors) } \\
\text { - Unstable active (some ready-to-use products may be formulated with } \\
\text { - stabilizers to achieve longer shelf life) } \\
\text { - Microbicidal activity affected by organic matter } \\
\text { - Discolors/stains fabrics } \\
\text { - Potential hazard is production of trihalomethane } \\
\text { - May cause skin and eye irritation } \\
\text { - Odor (some ready-to-use products may be formulated with odor } \\
\text { - Inhibitors) }\end{array}$ \\
\hline $\begin{array}{l}\text { Improved (or acceler- } \\
\text { ated) hydrogen } \\
\text { peroxide }\end{array}$ & $\begin{array}{l}\text { - Bactericidal, tuberculocidal, fungicidal, virucidal } \\
\text { - Fast efficacy } \\
\text { - Easy compliance with wet-treatment times } \\
\text { - Safe for workers (lowest EPA toxicity category, IV) } \\
\text { - Benign for the environment } \\
\text { - Nonstaining } \\
\text { - EPA-registered } \\
\text { - Nonflammable }\end{array}$ & $\begin{array}{l}\text { - More expensive than most other disinfecting actives } \\
\text { - Not sporicidal at low concentrations } \\
\text { - Some materials compatibility issues }\end{array}$ \\
\hline Iodophors & $\begin{array}{l}\text { - Bactericidal, mycobactericidal, virucidal } \\
\text { - Nonflammable } \\
\text { - Used for disinfecting blood culture bottles }\end{array}$ & $\begin{array}{l}\text { - Not sporicidal } \\
\text { - Shown to degrade silicone catheters } \\
\text { - Requires prolonged contact to kill fungi } \\
\text { - Stains surfaces } \\
\text { - Used mainly as an antiseptic rather than disinfectant }\end{array}$ \\
\hline Phenolics & $\begin{array}{l}\text { - Bactericidal, tuberculocidal, fungicidal, virucidal } \\
\text { - Inexpensive (in dilutable form) } \\
\text { - Nonstaining } \\
\text { - Nonflammable } \\
\text { - EPA-registered }\end{array}$ & $\begin{array}{l}\text { - Not sporicidal } \\
\text { - Absorbed by porous materials and irritate tissue } \\
\text { - Depigmentation of skin caused by certain phenolics } \\
\text { - Hyperbilirubinemia in infants when phenolic not prepared as } \\
\text { recommended }\end{array}$ \\
\hline $\begin{array}{l}\text { Quaternary ammonium } \\
\text { compounds (eg, } \\
\text { didecyl dimethyl } \\
\text { ammonium bromide, } \\
\text { dioctyl dimethyl } \\
\text { ammonium bromide) }\end{array}$ & $\begin{array}{l}\text { - Bactericidal, fungicidal, virucidal against enveloped viruses } \\
\text { (eg, HIV) } \\
\text { - Good cleaning agents } \\
\text { - EPA-registered } \\
\text { - Surface compatible } \\
\text { - Nonstaining } \\
\text { - Persistent antimicrobial activity when undisturbed } \\
\text { - Inexpensive (in dilutable form) }\end{array}$ & $\begin{array}{l}\text { - Not sporicidal } \\
\text { - In general, not tuberculocidal and virucidal against nonenveloped } \\
\text { viruses } \\
\text { - High water hardness and cotton/gauze can make less microbicidal } \\
\text { - A few reports documented asthma as result of exposure to benzalko- } \\
\text { nium chloride } \\
\text { - Microbicidal activity affected by organic matter } \\
\text { - Absorption by cotton, some wipes may diminish microbicidal activity } \\
\text { - Multiple outbreaks ascribed to contaminated benzalkonium chloride }\end{array}$ \\
\hline $\begin{array}{l}\text { Alcohol and quaternary } \\
\text { ammonium } \\
\text { compound }\end{array}$ & $\begin{array}{l}\text { - Bactericidal, tuberculocidal, fungicidal, virucidal (enveloped and many } \\
\text { nonenveloped viruses (such as adeno, rota, entero, rhino) } \\
\text { - Fast acting } \\
\text { - Surface compatible } \\
\text { - Nonstaining } \\
\text { - Persistent antimicrobial activity when undisturbed } \\
\text { - EPA-registered }\end{array}$ & $\begin{array}{l}\text { - Not sporicidal } \\
\text { - Evaporates more rapidly than water-based disinfectants }\end{array}$ \\
\hline $\begin{array}{l}\text { Peracetic acid/hydrogen } \\
\text { peroxide }\end{array}$ & $\begin{array}{l}\text { - Bactericidal, fungicidal, virucidal and sporicidal (eg, Clostridium difficile) } \\
\text { - Active in the presence of organic material } \\
\text { - Environmentally friendly by-products (acetic acid, } \mathrm{O}_{2}, \mathrm{H}_{2} \mathrm{O} \text { ) } \\
\text { - EPA-registered } \\
\text { - Surface compatible }\end{array}$ & $\begin{array}{l}\text { - Lack of stability } \\
\text { - Potential for material incompatibility (eg, brass, copper) } \\
\text { - More expensive than most other disinfecting actives } \\
\text { - Odor may be irritating } \\
\text { - Can cause mucous membrane and respiratory health effects }{ }^{68}\end{array}$ \\
\hline
\end{tabular}

Modified from Rutala and Weber ${ }^{1,29,43}$

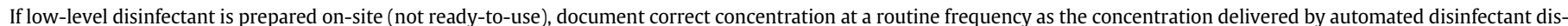
pensers vary. ${ }^{54}$

$E P A$, Environmental Protection Agency; IV, intravenous.

must be allowed to perform the job properly or the hospital risks poor patient outcomes via secondary spread via contaminated environmental surfaces and noncritical patient care devices. ${ }^{80}$ Some authors have suggested that if you follow the recommended practice steps, an occupied patient room clean will take 25-30 minutes, whereas a terminal room clean will take $40-45$ minutes. $^{80}$

\section{Improving Room Cleaning and Disinfection}

The cleaning/disinfection of noncritical surfaces in hospitals is essential for reducing microbial contamination and reducing HAIs. ${ }^{7,10,70}$ Compliance or enforcing routine environmental cleaning/ disinfecting measures has been associated with reduction of 
microbial contamination and/or reduction in HAIs in many studies. ${ }^{10,11,21-27,81}$ The Agency for Healthcare Research and Quality review offers an overview of the monitoring strategies to assess and improve environmental cleaning/disinfection. ${ }^{7,70}$ These include: visual inspection; microbiologic methods; fluorescent markers; and adenosine triphosphate (ATP) assays. Presently, polymerase chain reaction-based technology has a limited role for assessing environmental contamination, is investigational, and does not differentiate between the presence of viable and nonviable microorganisms. ${ }^{70}$

Investigators have reported that intervention programs aimed at ES workers resulted in significant improvement in cleaning practices. ${ }^{82-84}$ Such interventions have generally included multiple activities: improved education; monitoring the thoroughness of cleaning (eg, by use of ATP assays or fluorescent dyes) with feedback of performance to the ES workers; ${ }^{84}$ adequate time; and/or use of cleaning checklists. A checklist facilitates consistent quality and ensures ES staff know what they are supposed to do. We have found that assignment of cleaning responsibility (eg, environmental surfaces and noncritical medical devices such as Dinamaps, IV poles/pumps, and SCD pumps to be cleaned by ES) is also important to ensure all objects and surfaces are decontaminated, especially the surfaces of medical equipment (eg, cardiac monitors). Improved environmental cleaning has been demonstrated to reduce the environmental contamination with VRE, ${ }^{78,85}$ MRSA, $^{85}$ and $C$ difficile. ${ }^{27}$ Importantly, no study has reported in the postintervention period, proper cleaning of $>85 \%$ of objects. Further, all studies have only focused improvement on a limited number of "high risk" objects. ${ }^{19,82}$ Thus, a concern of published studies is that they have only demonstrated improved cleaning of a limited number of "high risk" objects (or "targeted" objects) not an improvement in the overall thoroughness of room decontamination.

Several studies have shown that educational interventions directed at ES, enhanced cleaning, and additional staff can result in improved decontamination of environmental surfaces and/or reduction of HAIs. ${ }^{10,11,21-27}$ Adequate staffing, as well as supervision, is essential to the success of the adherence to evidence-based cleaning/ disinfection practices (Table 1) and for the work to be completed properly. Increase staffing and modifications of practice (eg, 2-3 times daily disinfection during norovirus outbreak) may be needed in the presence of an outbreak. ${ }^{86}$ There are no guidelines in the United States regarding the time allotted for cleaning/disinfected patient rooms in hospitals ( $\mathrm{ft}^{2} /$ hour) ${ }^{87}$ In general, the hospital's practices (eg, frequency of cleaning) and the disinfectants used are based on the scientific literature (eg, a sporicidal agent [such as chlorine or peracetic acid/hydrogen peroxide (HP)] for $C$ difficile $)^{10}$ and not based of the vulnerability of patients (eg, intensive care units) ${ }^{86}$ as all patients in US hospitals are considered severely ill and highly susceptible to infection. Factors that affect staffing include: type of care area (eg, patient room; showers, toilets and baths; presence of carpet); occupancy factors (eg, frequency of cleaning required); equipment factors (eg, type of cleaning tools available [mop and bucket vs automated floor cleaner]); training factors (eg, staff experience); and regulatory requirements. ${ }^{86}$ The importance of ES staff in preventing infection transmission must be recognized by hospital administration. The " $C$ " suite must appreciate that ES is both a clinical department and an aesthetic department. ${ }^{80}$ Clinically, ES staff remove bacteria from surfaces that reduce the risk of infection via contaminated surfaces, ${ }^{5,10,11,19,21-27,73}$ and aesthetically, they provide a hygienically clean and safe place for the patient to recover. ${ }^{80}$

\section{Compliance Monitoring and Feedback}

Hospital cleanliness continues to attract patient attention, and in the United States it is still primarily assessed via visual cleanliness (eg, dust, organic debris) of surfaces, which is not a reliable indicator of microbial contamination. ${ }^{88,89}$ ATP bioluminescence measures organic debris (each unit has its own reading scale, $<250-500$ relative light units-RLU) but is not a reliable indicator of microbial contamination. ${ }^{70}$ Fluorescent marking is done with a transparent, easily cleaned, environmentally stable marking solution that fluoresces when exposed to an ultraviolet (UV) light. It is applied by the infection preventionist (IP) or ES manager after the patient is discharged and unknown to the ES staff. After ES cleaning, the markings are reassessed by the IP or ES manager and the thoroughness of cleaning monitored and the immediate feedback provided to the person(s) cleaning/disinfecting the room (eg, 4 of 10 marker surfaces wiped, $40 \%$ compliance with thoroughness of cleaning and disinfection). Microbiologic methods have also been used to evaluate microbial contamination of surfaces. ${ }^{19}$ This method can be costly and pathogenic specific. Although there are no accepted criteria for defining a surface as "clean" using microbiologic methods, some investigators have suggested that microbial contamination should be 2.5 colonyforming units (CFU) $/ \mathrm{cm}^{2}$ to $<5 \mathrm{CFU} / \mathrm{cm}^{2} .{ }^{83,90}$ Studies have shown that this level of contamination may be easily achievable as the microbial burden of room surfaces in 1 hospital went from $57 \mathrm{CFU} /$ Rodac (2.3 $\left.\mathrm{CFU} / \mathrm{cm}^{2}\right)$ to $8 \mathrm{CFU} /$ Rodac $\left(0.3 \mathrm{CFU} / \mathrm{cm}^{2}\right)$ prior to and after cleaning. ${ }^{91}$ Based on surface cleaning and disinfection practices that are used in the United States, a revised stricter pass benchmark for microbial contamination may need to be considered $\left(<1 \mathrm{CFU} / \mathrm{cm}^{2}\right)$.

Studies have demonstrated suboptimal cleaning by aerobic colony counts as well as the use of the ATP bioluminescence and fluorescent markers. ${ }^{19,89,92,93}$ For example, Carling et al ${ }^{82}$ assessed the thoroughness of terminal cleaning in the patient's immediate environment in 23 acute care hospitals (1,119 patient rooms) by using a transparent, stable solution that fluoresces when exposed to handheld UV light. The overall thoroughness of cleaning, expressed as a percent of surfaces evaluated, was $49 \%$ (range for all hospitals, 35\%-81\%). A study using ATP bioluminescence assays and aerobic cultures demonstrated that medical equipment frequently had not been disinfected as per protocol. $^{33}$

ATP bioluminescence and fluorescent markers are preferred to aerobic plate counts because they provide an immediate assessment of cleaning effectiveness. Two recent reviews reported ATP as a quick and objective monitoring method; however, it was poorly standardized with low specificity and sensitivity in detecting bacteria. ${ }^{70,94,95}$ In a comparison study of the 4 methods to assess cleaning, we found that the fluorescent marker was the most useful tool in determining how thoroughly a surface was wiped as it mimicked the microbiological data better than ATP. For example, compared with microbiological data (using benchmark of $2.5 \mathrm{CFU} / \mathrm{cm}^{2} \times 25 \mathrm{~cm}^{2} /$ Rodac $=62.5$ CFU/Rodac), $72 \%$ were classified as clean with fluorescent markers, compared to $27 \%$ were classified as clean compared to ATP. There was no statistical correlation between ATP levels and standard aerobic plate counts. ${ }^{96}$

A novel approach to improving the thoroughness of cleaning has been introduced and involves a color additive to the disinfectants (eg, bleach) that improves visualization of surface coverage and contact time to improve thoroughness of cleaning. ${ }^{97-99}$ The color additive for bleach disinfection wipes may reduce the corrosive damage of stainless steel. ${ }^{100}$ Studies should be done to demonstrate if use of a colorized disinfectant improves the thoroughness of cleaning/disinfection, reduces microbial contamination, and reduces HAIs.

\section{“No Touch" (or Mechanical) Methods for Room Decontamination}

As noted earlier, multiple studies have demonstrated that environmental surfaces and objects in rooms are frequently not properly cleaned and these surfaces may be important in transmission of health care-associated pathogens. Further, interventions aimed at improving cleaning thoroughness have demonstrated effectiveness in reducing microbial contamination on surfaces and/or HAIs ${ }^{10,11,21-27}$ as well as 
studies involving disinfectant product substitutions (eg, Quat to chlorine for $($ difficile) and studies involving "no touch" room decontamination technologies.,10,101 Nonetheless, many surfaces remain inadequately cleaned, and therefore potentially contaminated, and put the next patient at risk for the previous patient's pathogen. For this reason, several manufacturers have developed room disinfection units that can effectively decontaminate environmental surfaces and objects and/or inoculated test surfaces. ${ }^{3,102-135}$ The 2 systems that have been studied comprehensively and will be discussed are UV light and HP systems. ${ }^{126}$ These technologies supplement, but do not replace, standard cleaning and disinfection because surfaces must be physically cleaned of dirt and debris.

\section{UV Light for Room Decontamination}

UV irradiation has been used for the control of pathogenic microorganisms in a variety of applications, such as control of Legionellosis, as well as disinfection of air, surfaces, and instruments. ${ }^{136,137}$ At certain wavelengths, UV light will break the molecular bonds in DNA, thereby destroying the organism. UV-C has a characteristic wavelength of $200-270 \mathrm{~nm}$ (eg, $254 \mathrm{~nm}$ ), which lies in the germicidal active portion of the electromagnetic spectrum of 200-320 nm. Another UV device uses pulsed-xenon radiation, which produces UV light in the 200-320 $\mathrm{nm}$ range. The efficacy of UV irradiation is a function of many different parameters such as organic load, distance from the UV device, pathogen, dose, exposure time, lamp placement, direct or indirect line of sight from the device, room size and shape, intensity, reflection, and air movement patterns. Studies have systematically investigated how these parameters affect the effectiveness of $\mathrm{UV}^{126,138-140}$ as well as logistic and administrative challenges (eg, room identification, time pressures from bed control). ${ }^{141}$

Weber et al $^{126}$ summarized multiple studies that assessed the effectiveness of UV devices to inactivate microbes inoculated onto test surfaces that are then placed in a typical room. The most commonly tested organisms were epidemiologically important health care-associated pathogens and included MRSA, VRE, $C$ difficile, and Acinetobacter spp. In general, the studies showed $>3-\log _{10}$ vegetative bacteria can be killed on carriers in 5-25 minutes by UV-C, and UV-C requires greater time and energy to kill a spore-forming organisms such as $C$ difficile spores. ${ }^{102-110}$

\section{HP Systems for Room Decontamination}

Several systems that produce HP (eg, HP vapor, aerosolized dry mist HP) have been studied for their ability to decontaminate environmental surfaces, objects in hospital rooms, and unused medical supplies. ${ }^{142} \mathrm{HP}$ vapor has been used increasingly for the decontamination of rooms in health care. ${ }^{107,111-120,134}$ These investigators found that HP systems are a highly effective method for eradicating various pathogens (eg, MRSA, M tuberculosis, Serratia, C difficile spores, Clostridium botulinum spores) from inoculated carriers, rooms, furniture and equipment.

\section{Comparison of UV Irradiation versus HP for Room Decontamination}

The UV-C device studied and the systems that use HP have their own advantages and disadvantages ${ }^{143}$ and there is now ample evidence that these "no-touch" systems can reduce environmental contamination with health care-associated pathogens. However, each specific system should be studied, and its efficacy demonstrated before being introduced into health care facilities. The main advantage of both units is their ability to achieve substantial reductions in vegetative bacteria and reduce HAIs. As noted earlier, manual cleaning has been demonstrated to be suboptimal as many environmental surfaces are not cleaned. Another advantage is their ability to substantially reduce $C$ difficile as low-level disinfectants (such as quaternary ammonium compounds) have only limited or no measurable activity against spore-forming bacteria. ${ }^{143}$ Both systems are residual free and they decontaminate all exposed surfaces and equipment in the room.

The major disadvantages of both decontamination systems are the substantial capital equipment costs, the need to remove personnel and patients from the room, thus limiting their use to terminal room disinfection (must prevent/minimize exposure to UV and HP), the staff time needed to transport the system to rooms to be decontaminated and monitor its use, the need to physically clean the room of dust and debris, and the sensitivity to use parameters. There are several important differences between the 2 systems. The UV-C system offers faster decontamination that reduces the "down" time of the room before another patient can be admitted. The HP systems have been demonstrated to be more effective in eliminating spore-forming organisms. ${ }^{134,135}$ Whether this improved sporicidal activity is clinically important is unclear as studies have demonstrated that although environmental contamination is common in the rooms of patients with $C$ difficile infection, the level of contamination of $C$ difficile is relatively low (eg, level of $C$ difficile surface contamination below $1-\log _{10}$ $\left[<10\right.$ CFU per Rodac or $\left.25 \mathrm{~cm}^{2}\right]$ ), which is also true for MRSA and VRE.

In the past 10 years, multiple trials have assessed the efficacy of UV and HP room decontamination units for reducing HAIs. There are at least 6 clinical trials that demonstrate a reduction of HAIs with the use of HP systems and 7 clinical trials that demonstrate a reduction in HAIs with UV. ${ }^{3,126}$ However, 11 of these studies used a before-after design that is more likely subject to bias than cross-over studies or randomized clinical trials. Two studies used a stronger epidemiologic design, either a prospective cohort ${ }^{131}$ or randomized clinical trial. ${ }^{105}$ Specifically, the later study was a prospective, multicenter, clusterrandomized, crossover trial in 9 hospitals that evaluated 3 strategies for enhanced room disinfection (ie, Quat plus UV-C; bleach alone, and bleach plus UV-C) compared to the standard strategy (ie, Quat). The study showed that enhanced room decontamination strategies (ie, bleach and/or UV-C decontamination) decreased the clinical incidence of acquisition of target multidrug resistant organisms (ie, MRSA, VRE, $C$ difficile) by $\sim 10 \%-30 \%(P=.036)$. Comparing the best strategy with the worst strategy (ie, Quat vs Quat/UV) revealed that a reduction of $94 \%$ in epidemiologically important pathogens (ie, 60.8 vs 3.4$)$ led to a $35 \%$ decrease in colonization/infection $(2.3 \%$ vs $1.5 \%) .{ }^{144}$ These data demonstrated that a decrease in room contamination was associated with a decrease in patient colonization/infection. To our knowledge, this is the first study that quantitatively described the entire pathway whereby improved disinfection decreases microbial contamination that in-turn reduced patient colonization/infection. ${ }^{105,144}$

Based on these data, hospitals should use a "no touch" device for terminal room decontamination after discharge of patients on contact precautions. However, the multitude of commercially available devices makes choosing a device difficult. UV devices may vary because of differences in UV wavelength, dose, ability to measure dose, and cost. Similarly, HP devices may differ regarding concentration, method of injecting HP into the room, dissemination of the HP in the room, and cost. For these reasons, IPs should review the peer-reviewed literature and choose for purchase only devices with demonstrated bactericidal capability as assessed by carrier test method and/or ability to disinfect actual rooms. Ideally, one should choose only "no touch" devices that have demonstrated the ability to reduce HAIs.,126

\section{Continuous Room Decontamination}

Even after cleaning and disinfection surfaces can rapidly become recontaminated. Thus, hands of health care providers can become colonized by touching contaminated environmental surfaces and patient care equipment and then, via inadequate hand hygiene or inappropriate 
glove use, can transfer health care pathogens from health care providerto-patient. Considering that routine cleaning of room surfaces by ES is frequently inadequate, continuous room decontamination methods are being evaluated. The intent of this technology is to make surfaces hygienically clean (not sterile), that is free of pathogens in sufficient numbers to prevent human disease. These include: visible light disinfection (highintensity narrow-spectrum light) ${ }^{145,146}$ low concentration HP; persistent disinfectants; ${ }^{147-150}$ and self-disinfection surfaces (eg, copper). ${ }^{151}$ These methods are under active investigation but, to date, have not been assessed for their ability to reduce HAIs. ${ }^{151}$

\section{SUMMARY}

A bundle requires all elements to be evidence-based and implemented uniformly and completely. The steps are simple and common sense and include: creating policies and procedures; selection of cleaning and disinfecting products; educating staff to include ES, patient equipment, and nursing; monitoring compliance and feedback; implement "no touch" room decontamination technology; and ensure compliance for patients on contact and enteric precautions.

\section{References}

1. Rutala WA, Weber DJ. Disinfection, sterilization, and control of hospital waste. In: Bennett JE, Dolan R, Blaser MJ, editors. Principles and practice of infectious diseases. 9th ed. Philadelphia (PA): Elsevier; In press.

2. Weber DJ, Rutala WA, Miller MB, Huslage K, Sickbert-Bennett E. Role of hospital surfaces in the transmission of emerging health care-associated pathogens: norovirus, Clostridium difficile, and Acinetobacter species. Am J Infect Control 2010;38 (5 Suppl 1):25-33.

3. Weber DJ, Kanamori H, Rutala WA. "No touch" technologies for environmental decontamination: focus on ultraviolet devices and hydrogen peroxide systems. Curr Opin Infect Dis 2016;29:424-31.

4. Weber DJ, Anderson D, Rutala WA. The role of the surface environment in healthcare-associated infections. Curr Opin Infect Dis 2013;26:338-44.

5. Otter JA, Yezli S, Salkeld JA, French GL. Evidence that contaminated surfaces contribute to the transmission of hospital pathogens and an overview of strategies to address contaminated surfaces in hospital settings. Am J Infect Control 2013;41(5 Suppl):6-11.

6. Boyce JM. Environmental contamination makes an important contribution to hospital infection. J Hosp Infect 2007;65(Suppl 2):50-4.

7. Han JH, Sullivan N, Leas BF, Pegues DA, Kaczmarek JL, Umscheid CA. Cleaning hospital room surfaces to prevent health care-associated infections. Ann Intern Med 2015.

8. John A, Alhmidi H, Cadnum JL, Jencson AL, Donskey CJ. Contaminated portable equipment is a potential vector for dissemination of pathogens in the intensive care unit. Infect Control Hosp Epidemiol 2017;38:1247-9.

9. Piedrahita CT, Cadnum JC, Jencson AL, Shaikh AA, Ghannoum MA, Donskey CJ. Environmental surfaces in healthcare facilities are a potential source for transmission of Candida auris and other Candida species. Infect Control Hosp Epidemiol 2017;38:1107-9

10. Donskey CJ. Does improving surface cleaning and disinfection reduce health careassociated infections? Am J Infect Control 2013;41(5 Suppl):12-9.

11. Datta R, Platt R, Yokoe DS, Huang SS. Environmental cleaning intervention and risk of acquiring multidrug-resistant organisms from prior room occupants. Arch Intern Med 2011;171:491-4.

12. Doll M, Stevens M, Bearman G. Environmental cleaning and disinfection of patient areas. Int J Infect Dis 2018;67:52-7.

13. Hota B. Contamination, disinfection, and cross-colonization: are hospital surfaces reservoirs for nosocomial infection? Clin Infect Dis 2004;39:1182-9.

14. Kramer A, Schwebke I, Kampf G. How long do nosocomial pathogens persist on inanimate surfaces? A systematic review. BMC Infect Dis 2006;6:130.

15. Suleyman G, Alangaden G, Bardossy AC. The role of environmental contamination in the transmission of nosocomial pathogens and healthcare-associated infections. Curr Infect Dis Rep 2018;20:12.

16. Shams AM, Rose LJ, Edwards JR, et al. Assessment of the overall and multidrugresistant organism bioburden on environmental surfaces in healthcare facilities. Infect Control Hosp Epidemiol 2016;37:1426-32.

17. Siani $\mathrm{H}$, Maillard JY. Best practice in healthcare environment decontamination. Eur J Clin Microbiol Infect Dis 2015;34:1-11.

18. Stiefel U, Cadnum JL, Eckstein BC, Guerrero DM, Tima MA, Donskey CJ. Contamination of hands with methicillin-resistant Staphylococcus aureus after contact with environmental surfaces and after contact with the skin of colonized patients. Infect Control Hosp Epidemiol 2011;32:185-7.

19. Carling P. Methods for assessing the adequacy of practice and improving room disinfection. Am J Infect Control 2013;41:20-5.
20. Shaughnessy MK, Micielli RL, DePestel DD, et al. Evaluation of hospital room assignment and acquisition of Clostridium difficile infection. Infect Control Hosp Epidemiol 2011;32:201-6.

21. Hayden MK, Bonten MJ, Blom DW, Lyle EA, van de Vijver DA, Weinstein RA Reduction in acquisition of vancomycin-resistant enterococcus after enforcement of routine environmental cleaning measures. Clin Infect Dis 2006;42:1552-60.

22. Falk PS, Winnike J, Woodmansee C, Desai M, Mayhall CG. Outbreak of vancomycin-resistant enterococci in a burn unit. Infect Control Hosp Epidemiol 2000;21:575-82.

23. Denton M, Wilcox MH, Parnell P, et al. Role of environmental cleaning in controlling an outbreak of Acinetobacter baumannii on a neurosurgical intensive care unit. J Hosp Infect 2004;56:106-10.

24. Rampling A, Wiseman S, Davis L, et al. Evidence that hospital hygiene is important in the control of methicillin-resistant Staphylococcus aureus. J Hosp Infect 2001;49:109-16.

25. Grabsch EA, Mahony AA, Cameron DR, et al. Significant reduction in vancomycinresistant enterococcus colonization and bacteraemia after introduction of a bleach-based cleaning-disinfection programme. J Hosp Infect 2012;82:234-42.

26. Wilson AP, Smyth D, Moore G, et al. The impact of enhanced cleaning within the intensive care unit on contamination of the near-patient environment with hospital pathogens: a randomized crossover study in critical care units in two hospitals. Crit Care Med 2011;39:651-8.

27. Eckstein BC, Adams DA, Eckstein EC, et al. Reduction of Clostridium difficile and vancomycin-resistant Enterococcus contamination of environmental surfaces after an intervention to improve cleaning methods. BMC Infect Dis 2007;7:61

28. Rutala WA, Weber DJ. Monitoring and improving the effectiveness of surface cleaning and disinfection. Am J Infect Control 2016;44:e69-76.

29. Rutala WA, Weber DJ. Selection of the ideal disinfectant. Infect Control Hosp Epidemiol 2014;35:855-65.

30. Havill NL. Best practices in disinfection of noncritical surfaces in the health care setting: creating a bundle for success. Am J Infect Control 2013:41:26-30

31. Kanamori H, Rutala WA, Weber DJ. The role of patient care items as a fomite in healthcare-associated outbreaks and infection prevention. Clin Infect Dis 2017:65:1412-9.

32. Suwantarat N, Supple LA, Cadnum JL, Sankar T, Donskey CJ. Quantitative assessment on interactions between hospitalized patients and portable medical equipment and other fomites. Am J Infect Control 2017;45:1276-8.

33. Havill NL, Havill HL, Mangione E, Dumigan DG, Boyce JM. Cleanliness of portable medical equipment disinfected by nursing staff. Am J Infect Control 2011;39: 602-4.

34. Deshpande A, Cadnum JL, Fertelli D, et al. Are hospital floors an underappreciated reservoir for transmission of health care-associated pathogens. Am J Infect Control 2017; 45:336-8.

35. Koganti S, Alhmidi H, Tomas ME, Cadnum IL, Jencson A, Donskey CJ. Evaluation of hospital floors as a potential source of pathogen dissemination using a nonpathogenic virus as a surrogate marker. Infect Control Hosp Epidemiol 2016;37:1374-7.

36. Huslage K, Rutala WA, Sickbert-Bennett E, Weber DJ. A quantitative approach to defining "high-touch" surfaces in hospitals. Infect Control Hosp Epidemiol 2010;31:850-3.

37. Weber DJ, Rutala WA. Environmental issues and nosocomial infections. In: Wenzel RP, ed. Prevention and control of nosocomial infections, 3rd ed. Baltimore (MD): Williams and Wilkins; 1997:491-514.

38. Best M, Sattar SA, Springthorpe VS, Kennedy ME. Efficacies of selected disinfectants against Mycobacterium tuberculosis. J Clin Microbiol 1990;28:2234-9.

39. Best M, Kennedy ME, Coates F. Efficacy of a variety of disinfectants against Listeria spp. Appl Environ Microbiol 1990;56:377-80.

40. Best M, Springthorpe VS, Sattar SA. Feasibility of a combined carrier test for disinfectants: studies with a mixture of five types of microorganisms. Am J Infect Control 1994;22:152-62

41. Rutala WA, Barbee SL, Aguiar NC, Sobsey MD, Weber DJ. Antimicrobial activity of home disinfectants and natural products against potential human pathogens. Infect Control Hosp Epidemiol 2000;21:33-8.

42. Rutala WA, Gergen MF, Weber DJ. Efficacy of improved hydrogen peroxide against important healthcare-associated pathogens. Infect Control Hosp Epidemiol 2012;33:1159-61.

43. Centers for Disease Control and Prevention. Guideline for disinfection and sterilization in healthcare facilities, 2008 Centers for Disease Control and Prevention. Available from: http://www.cdc.gov/ncidod/dhqp/pdf/guidelines/Disinfection_Nov_2008.pdf. Accessed January 15, 2019.

44. West AM, Teska PJ, Oliver HF. There is no additional bactericidal efficacy of Environmental Protection Agency-registered disinfectant towelettes after surface drying or beyond label contact time. Am J Infect Control 2019;47:27-32.

45. Rutala WA, Weber DJ. Surface disinfection: treatment time (wipes and sprays) versus contact time (liquids). Infect Control Hosp Epidemiol 2018;39:329-31.

46. Kenters N, Huijskens EGW, de Wit SCJ, van Rosmalen J, Voss A. Effectiveness of cleaning-disinfection wipes and sprays against multidrug-resistant outbreak strains. Am J Infect Control 2017:45:e69-73.

47. Rutala WA, Gergen MF, Weber DJ. Efficacy of different cleaning and disinfection methods against Clostridium difficile spores: importance of physical removal versus sporicidal inactivation. Infect Control Hosp Epidemiol 2012;33:1255-8.

48. Gonzalez EA, Nandy P, Lucas AD, Hitchins VM. Ability of cleaning-disinfecting wipes to remove bacteria from medical device surfaces. Am J Infect Control 2015;43:1331-5. 
49. Sifuentes LY, Gerba CP, Weart I, Engelbrecht K, Koenig DW. Microbial contamination of hospital reusable cleaning towels. Am J Infect Control 2013;41:912-5.

50. Sooklal S, Khan A, Kannangara S. Hospital Clostridium difficile outbreak linked to laundry machine malfunction. Am J Infect Control 2014;42:674-5.

51. Westwood JC, Mitchell MA, Legacé S. Hospital sanitation: the massive bacterial contamination of the wet mop. Appl Microbiol 1971;21:693-7.

52. Rutala WA, Gergen MF, Weber DJ. Microbiologic evaluation of microfiber mops for surface disinfection. Am J Infect Control 2007:35:569-73.

53. Engelbrecht K, Ambrose D, Sifuentes L, Gerba C, Weart I, Koenig D. Decreased activity of commercially available disinfectants containing quaternary ammonium compounds when exposed to cotton towels. Am J Infect Control 2013;41: 908-11.

54. Boyce JM, Sullivan L, Booker A, Baker J. Quaternary ammonium disinfectant issues encountered in an environmental services department. Infect Control Hosp Epidemiol 2016:37:340-2.

55. MacDougall KD, Morris C. Optimizing disinfectant application in healthcare facilities. Infect Control Today 2006; June:62-7.

56. Vickery K, Deva A, Jacombs A, Allan J, Valente P, Gosbell IB. Presence of biofilm containing viable multiresistant organisms despite terminal cleaning on clinical surfaces in an intensive care unit. J Hosp Infect 2012;80:52-5.

57. Otter JA, Vickery K, Walker JT, et al. Surface-attached cells, biofilms and biocide susceptibility: implications for hospital cleaning and disinfection. J Hosp Infect 2015;89:16-27.

58. Ledwoch K, Dancer S, Otter JA, Kerr K, Roposte D, Rushton L, et al. Beware biofilm! Dry biofilms containing bacterial pathogens on multiple healthcare surfaces: a multi-center study. J Hosp Infect 2018;100:e47-56

59. Almatroudi A, Gosbell IB, Hu H, Jensen SO, Espedido BA, Tahir S, et al. Staphylococcus aureus dry-surface biofilms are not killed by sodium hypochlorite: implications for infection control. J Hosp Infect 2016;93:263-70.

60. Song L, Wu J, Xi C. Biofilms on environmental surfaces: evaluation of the disinfection efficacy of a novel steam vapor system. Am J Infect Control 2012:40:926-30.

61. Teska PJ, Li X, Gauthier J. Wet contact time directly impacts antimicrobial efficacy of Environmental Protection Agency-registered disinfectants. Am J Infect Control 2018

62. Rutala WA. Risk-assessment worksheet for 1 minute contact time for low-level disinfectants. 2018. Available from: https://disinfectionandsterilization.org/resources/ disinfection-risk-assessment-2016/. Accessed January 15, 2019.

63. Haraden C. What is a bundle. Institute for Healthcare Improvement. Available from: http://www.ihi.org/resources/Pages/ImprovementStories/WhatIsaBundle. aspx. Accessed

64. Dumigan DG, Boyce JM, Havill NL, Golebiewski M, Balogun O, Rizvani R. Who is really caring for your environment of care? Developing standardized cleaning procedures and effective monitoring techniques. Am J Infect Control 2010;38:387-92.

65. Molinari JA, Gleason MJ, Cottone JA, Barrett ED. Comparison of dental surface disinfectants. Gen Dent 1987;35:171-5.

66. Weber DJ, Rutala WA, Sickbert-Bennett EE. Outbreaks associated with contaminated antiseptics and disinfectants. Antimicrob Agents Chemother 2007:51:4217-24.

67. Rutala WA, Cole EC, Thomann CA, Weber DJ. Stability and bactericidal activity of chlorine solutions. Infect Control Hosp Epidemiol 1998;19:323-7.

68. Hawley B, Casey ML, Cox-Ganser JM, Edwards N, Fedan KB, Cummings KJ. Notes from the field: respiratory symptoms and skin irritation among hospital workers using a new disinfection product-Pennsylvania, 2015. MMWR Morb Mortal Wkly Rep 2016:65:400-1.

69. Rutala WA, Gergen MF, Sickbert-Bennett EE, Williams DA, Weber DJ. Effectiveness of improved hydrogen peroxide in decontaminating privacy curtains contaminated with multidrug-resistant pathogens. Am J Infect Control 2014;42:426-

70. Leas BF, Sullivan N, Han JH, Pegues DA, Kaczmarek JL, Umscheid CA. Environmental cleaning for the prevention of healthcare-associated infection. Technical brief No. 22 (prepared by the ECRI Institute-Penn Agency for Healthcare Research and Quality). Available from: http://www.effectivehealthcare.ahrq.gov/ehc/products/ 592/2103/healthcare-infections-report-150810.pdf2015. Accessed

71. Wenzel RP, Edmond MB. Infection control: the case for horizontal rather than vertical interventional programs. Int J Infect Dis 2010;14(Suppl 4):3-5.

72. Anonymous. How to select an ideal disinfectant. Infection Control Today 2009, 2009; June Available from: http://wwwinfectioncontroltodaycom/articles/2009/ 05/how-to-select-an-ideal-disinfectantaspx Accessed January 15, 2019.

73. Otter JA, Yezli S, French GL. The role played by contaminated surfaces in the transmission of nosocomial pathogens. Infect Control Hosp Epidemiol 2011:32:687-99.

74. Rutala WA, Weber DJ. The benefits of surface disinfection. Am J Infect Control 2005;33:434-5.

75. Alfa MJ, Lo E, Olson N, MacRae M, Buelow-Smith L. Use of a daily disinfectant cleaner instead of a daily cleaner reduced hospital-acquired infection rates. Am J Infect Control 2015;43:141-6.

76. Ramm L, Siani H, Wesgate R, Maillard JY. Pathogen transfer and high variability in pathogen removal by detergent wipes. Am J Infect Control 2015;43:724-8.

77. Cadnum JL, Hurless KN, Kundrapu S, Donskey CJ. Transfer of Clostridium difficile spores by nonsporicidal wipes and improperly used hypochlorite wipes: practice + product $=$ perfection. Infect Control Hosp Epidemiol 2013:34:441-2.

78. Hota B, Blom DW, Lyle EA, Weinstein RA, Hayden MK. Interventional evaluation of environmental contamination by vancomycin-resistant enterococci: failure of personnel, product or procedure? J Hosp Infect 2009;71:123-31.
79. Boyce JM, Havill NL, Lipka A, Havill H, Rizvani R. Variations in hospital daily cleaning practices. Infect Control Hosp Epidemiol 2010;31:99-101.

80. Pyrek KM. Room turnover times: trash-and-dash approach jeopardizes patient outcomes. Infect Control Today 2015(September):12-26.

81. Sitzlar B, Deshpande A, Fertelli D, Kundrapu S, Sethi AK, Donskey CJ. An environmental disinfection odyssey: evaluation of sequential interventions to improve disinfection of Clostridium difficile isolation rooms. Infect Control Hosp Epidemiol 2013:34:459-65.

82. Carling PC, Parry MF, Von Beheren SM;. Healthcare Environmental Hygiene Study Group. Identifying opportunities to enhance environmental cleaning in 23 acute care hospitals. Infect Control Hosp Epidemiol 2008;29:1-7.

83. Lewis T, Griffith C, Gallo M, Weinbren M. A modified ATP benchmark for evaluating the cleaning of some hospital environmental surfaces. J Hosp Infect 2008;69:156-63.

84. Carling P, Herwaldt LA. The Iowa disinfection cleaning project: opportunities, successes, and challenges of a structured intervention program in 56 hospitals. Infect Control Hosp Epidemiol 2017;38:960-5.

85. Goodman ER, Platt R, Bass R, Onderdonk AB, Yokoe DS, Huang SS. Impact of an environmental cleaning intervention on the presence of methicillin-resistant Staphylococcus aureus and vancomycin-resistant enterococci on surfaces in intensive care unit rooms. Infect Control Hosp Epidemiol 2008;29:593-9.

86. Ministry of Health S. Environmental cleaning guidelines for healthcare settings. Available from: https://wwwmohgovsg/content/dam/moh_web/Publications/ Guidelines/Infection\%20Control\%20guidelines/Environmental\%20Cleaning\%20Guidelines-Jun\%202013pdf2013. Accessed January 15, 2019.

87. Hausemann A, Grünewald M, Otto U, Heudorf U. Cleaning and disinfection of surfaces in hospitals. Improvement in quality of structure, process and outcome in the hospitals in Frankfurt/Main, Germany, in 2016 compared to 2014. GMS Hyg Infect Control 2018;13, Doc06.

88. Cooper RA, Griffith CJ, Malik RE, Obee P, Looker N. Monitoring the effectiveness of cleaning in four British hospitals. Am J Infect Control 2007:35:338-41.

89. Guh A, Carling P. Options for evaluating environmental cleaning. Available from: http://www.cdc.gov/HAI/toolkits/Environ-Cleaning-Eval-Toolkit-10-6-2010. pdf2010. Accessed

90. Dancer SJ. How do we assess hospital cleaning? A proposal for microbiological standards for surface hygiene in hospitals. J Hosp Infect 2004;56:10-5

91. Huslage K, Rutala WA, Gergen MF, Sickbert-Bennett EE, Weber DJ. Microbial assessment of high, medium-, and low-touch hospital room surfaces. Infect Control Hosp Epidemiol 2013;34:211-2

92. Boyce JM, Havill NL, Dumigan DG, Golebiewski M, Balogun O, Rizvani R. Monitoring the effectiveness of hospital cleaning practices by use of an adenosine triphosphate bioluminescence assay. Infect Control Hosp Epidemiol 2009;30:678-84

93. Carling PC, Briggs JL, Perkins J, Highlander D. Improved cleaning of patient rooms using a new targeting method. Clin Infect Dis 2006;42:385-8.

94. Mitchell BG, Dancer SJ, Shaban RZ, Graves N. Moving forward with hospital cleaning. Am J Infect Control 2013;41:1138-9.

95. Amodio E, Dino C. Use of ATP bioluminescence for assessing the cleanliness of hospital surfaces: a review of the published literature (1990-2012). J Infect Public Health 2014;7:92-8.

96. Rutala WA, Kanamori H, Gergen MF, Sickbert-Bennett E, Huslage K, Weber DJ. Comparative analysis of four major hospital cleaning validation methods. Am J Infect Control 2017;45:37.

97. Tyan K, Jin K, Kang J. A novel color additive for bleach wipes indicates surface coverage and contact time to improve thoroughness of cleaning. Infect Control Hosp Epidemiol 2019;40:256-8.

98. Mustapha A, Cadnum JL, Alhmidi H, Donskey CJ. Evaluation of novel chemical additive that colorizes chlorine-based disinfectants to improve visualization of surface coverage. Am J Infect Control 2017;46:119-21.

99. Kang J, Tyan KS, Jin K, Kyle AM. Field testing of a novel colour indicator added to chlorine solutions used for decontamination of surfaces in Ebola treatment units. J Hosp Infect 2018;99:188-91.

100. Tyan K, Jin K, Kang J. Novel colour additive for bleach disinfectant wipes reduces corrosive damage on stainless steel. J Hosp Infect 2018

101. Boyce JM. Modern technologies for improving cleaning and disinfecting of environmental surfaces in hospitals. Antimicrob Resist Infect Control 2016;5:10.

102. Rutala WA, Gergen MF, Weber DJ. Room decontamination with UV radiation. Infect Control Hosp Epidemiol 2010;31:1025-9.

103. Rutala WA, Weber DJ, Gergen MF, Tande BM, Sickbert-Bennett EE. Does coating all room surfaces with an ultraviolet C light-nanoreflective coating improve decontamination compared with coating only the walls? Infect Control Hosp Epidemiol 2014;35:323-5.

104. Anderson DJ, Gergen MF, Smathers E, et al. Decontamination of targeted pathogens from patient rooms using an automated ultraviolet-C-emitting device. Infect Control Hosp Epidemiol 2013:34:466-71.

105. Anderson DJ, Chen LF, Weber DJ, Moehring RW, Lewis SS, et al. The benefits of enhanced terminal room (BETR) disinfection study: a prospective, cluster randomized, multicenter, crossover study to evaluate the impact of enhanced terminal room disinfection on acquisition and infection caused by multidrug-resistant organisms. Lancet 2017;389:805-14.

106. Boyce JM, Havill NL, Moore BA. Terminal decontamination of patient rooms using an automated mobile UV light unit. Infect Control Hosp Epidemiol 2011:32:737-42.

107. Havill NL, Moore BA, Boyce JM. Comparison of the microbiological efficacy of hydrogen peroxide vapor and ultraviolet light processes for room decontamination. Infect Control Hosp Epidemiol 2012;33:507-12. 
108. Nerandzic MM, Cadnum JL, Pultz MJ, Donskey CJ. Evaluation of an automated ultraviolet radiation device for decontamination of Clostridium difficile and other healthcare-associated pathogens in hospital rooms. BMC Infect Dis 2010;10:197.

109. Nerandzic MM, Thota P, Sankar CT, et al. Evaluation of a pulsed xenon ultraviolet disinfection system for reduction of healthcare-associated pathogens in hospital rooms. Infect Control Hosp Epidemiol 2015;36:192-7.

110. Jinadatha C, Villamaria FC, Ganachari-Mallappa N, et al. Can pulsed xenon ultraviolet light systems disinfect aerobic bacteria in the absence of manual disinfection? Am J Infect Control 2015;43:415-7.

111. Bates CJ, Pearse R. Use of hydrogen peroxide vapour for environmental control during a Serratia outbreak in a neonatal intensive care unit. J Hosp Infect 2005;61:364-6.

112. Boyce JM, Havill NL, Otter JA, et al. Impact of hydrogen peroxide vapor room decontamination on Clostridium difficile environmental contamination and transmission in a healthcare setting. Infect Control Hosp Epidemiol 2008;29:723-9.

113. French GL, Otter JA, Shannon KP, Adams NM, Watling D, Parks MJ. Tackling contamination of the hospital environment by methicillin-resistant Staphylococcus aureus (MRSA): a comparison between conventional terminal cleaning and hydrogen peroxide vapour decontamination. J Hosp Infect 2004;57:31-7.

114. Bartels MD, Kristoffersen K, Slotsbjerg T, Rohde SM, Lundgren B, Westh H. Environmental methicillin-resistant Staphylococcus aureus (MRSA) disinfection using dry-mist-generated hydrogen peroxide. J Hosp Infect 2008;70:35-41.

115. Hall L, Otter JA, Chewins J, Wengenack NL. Use of hydrogen peroxide vapor for deactivation of Mycobacterium tuberculosis in a biological safety cabinet and a room. J Clin Microbiol 2007;45:810-5.

116. Hardy KJ, Gossain S, Henderson N, et al. Rapid recontamination with MRSA of the environment of an intensive care unit after decontamination with hydrogen peroxide vapour. J Hosp Infect 2007;66:360-8.

117. Johnston MD, Lawson S, Otter JA. Evaluation of hydrogen peroxide vapour as a method for the decontamination of surfaces contaminated with Clostridium botulinum spores. J Microbiol Methods 2005;60:403-11.

118. Klapes NA, Vesley D. Vapor-phase hydrogen peroxide as a surface decontaminant and sterilant. Appl Environ Microbiol 1990;56:503-6.

119. Shapey S, Machin K, Levi K, Boswell TC. Activity of a dry mist hydrogen peroxide system against environmental Clostridium difficile contamination in elderly care wards. J Hosp Infect 2008;70:136-41.

120. Otter JA, Barnicoat M, Down J, Smyth D, Yezli S, Jeanes A. Hydrogen peroxide vapour decontamination of a critical care unit room used to treat a patient with Lassa fever. J Hosp Infect 2010;75:335-7.

121. Mana TS, Sitzlar B, Cadnum JL, Jencson AL, Koganti S, Donskey CJ. Evaluation of an automated room decontamination device using aerosolized peracetic acid. Am J Infect Control 2017;45:327-9.

122. Blazejewski $\mathrm{V}$, Wallet $\mathrm{F}$, Rouze $\mathrm{A}$, et al. Efficiency of hydrogen peroxide in improving disinfection in ICU rooms. Crit Care 2015;19:30

123. Anderson DJ, Moehring RW, Weber DJ, et al. Effectiveness of targeted enhanced terminal room disinfection on hospital-wide acquisition and infection with multidrug-resistant organisms and Clostridium difficile: a secondary analysis of a multicentre cluster randomised controlled trial with crossover design (BETR Disinfection). Lancet Infect Dis 2018;18:845-53.

124. Rutala WA, Kanamori H, Gergen MF, et al. Enhanced disinfection leads to reduction of microbial contamination and a decrease in patient colonization and infection. Infect Control Hosp Epidemiol 2018;39:1118-21.

125. Raggi R, Archulet K, Haag CW, Tang W. Clinical, operational and financial impact of an ultraviolet-C terminal disinfection intervention at a community hospital. Am J Infect Control 2018;46:1224-9.

126. Weber DJ, Rutala WA, Anderson DJ, Chen LF, Sickbert-Bennett EE, Boyce JM. Effectiveness of UV devices and hydrogen peroxide systems for terminal room decontamination: focus on clinical trials. Am J Infect Control 2016;44:e77-84.

127. Andersen BM, Bånrud $\mathrm{H}, \mathrm{B} ø \mathrm{e} \mathrm{E}$, Bjordal O, Drangsholt F. Comparison of UV C light and chemicals for disinfection of surfaces in hospital isolation units. Infect Control Hosp Epidemiol 2006;27:729-34.

128. Yui S, Ali S, Muzslay M, Jeanes A, Wilson APR. Identification of Clostridium difficile reservoirs in the patient environment and efficacy of aerial hydrogen peroxide decontamination. Infect Control Hosp Epidemiol 2017;38:1487-92.

129. Rutala WA, Gergen MF, Tande BM, Weber DJ. Room decontamination using an ultraviolet-C device with short ultraviolet exposure time. Infect Control Hosp Epidemiol 2014;35:1070-2.
130. Rutala WA, Gergen MF, Tande BM, Weber DJ. Rapid hospital room decontamination using ultraviolet (UV) light with a nanostructured UV-reflective wall coating. Infect Control Hosp Epidemiol 2013;34:527-9.

131. Pegues DA, Han J, Gilmar C, McDonnell B, Gaynes S. Impact of ultraviolet germicidal irradiation for no-touch terminal room disinfection on Clostridium difficile infection incidence among hematology-oncology patients. Infect Control Hosp Epidemiol 2017;38:39-44.

132. Passaretti CL, Otter JA, Reich NG, et al. An evaluation of environmental decontamination with hydrogen peroxide vapor for reducing the risk of patient acquisition of multidrug-resistant organisms. Clin Infect Dis 2013;56:27-35.

133. Levin J, Riley LS, Parrish C, English D, Ahn S. The effect of portable pulsed xenon ultraviolet light after terminal cleaning on hospital-associated Clostridium difficile infection in a community hospital. Am J Infect Control 2013;41:746-8.

134. Lemmen S, Scheithauer S, Hafner H, Yezli S, Mohr M, Otter JA. Evaluation of hydrogen peroxide vapor for the inactivation of nosocomial pathogens on porous and nonporous surfaces. Am J Infect Control 2015;43:82-5.

135. Otter JA, French GL. Survival of nosocomial bacteria and spores on surfaces and inactivation by hydrogen peroxide vapor. J Clin Microbiol 2009;47:205-7.

136. Rutala WA, Weber DJ. Are room decontamination units needed to prevent transmission of environmental pathogens? Infect Control Hosp Epidemiol 2011;32: 743-7.

137. Memarzadeh F, Olmsted RN, Bartley JM. Applications of ultraviolet germicidal irradiation disinfection in health care facilities: effective adjunct, but not standalone technology. Am J Infect Control 2010;38:13-24.

138. Cadnum JL, Tomas ME, Sankar T, et al. Effect of variation in test methods on performance of ultraviolet-C radiation room decontamination. Infect Control Hosp Epidemiol 2016;37:555-60.

139. Tande BM, Pringle TA, Rutala WA, Gergen MF, Weber DJ. Understanding the effect of ultraviolet light intensity on disinfection performance through the use of ultraviolet measurements and simulation. Infect Control Hosp Epidemiol 2018;39: 1122-4.

140. Zhang A, Nerandzic MM, Kundrapu S, Donskey CJ. Does organic material on hospital surfaces reduce the effectiveness of hypochlorite and UV radiation for disinfection of Clostridium difficile? Infect Control Hosp Epidemiol 2013;34:11068 .

141. Anderson DJ, Knelson LP, Moehring RW, et al. Implementation lessons learned from the benefits of enhanced terminal room (BETR) disinfection study: process and perceptions of enhanced disinfection with ultraviolet disinfection devices. Infect Control Hosp Epidemiol 2018;39:157-63.

142. Otter JA, Nowakowski E, Salkeld JA, et al. Saving costs through the decontamination of the packaging of unused medical supplies using hydrogen peroxide vapor. Infect Control Hosp Epidemiol 2013;34:472-8.

143. Rutala WA, Weber DJ. Disinfectants used for environmental disinfection and new room decontamination technology. Am J Infect Control 2013;41:36-41.

144. Rutala WA, Kanamori H, Gergen MF, Knelson LP, Sickbert-Bennett EE, Chen LF, et al. Enhanced disinfection leads to reduction of microbial contamination and a decrease in patient colonization and infection. Infect Control Hosp Epidemiol 2018;39:1118-21.

145. Rutala WA, Kanamori H, Gergen MF, et al. Antimicrobial activity of a continuous visible light disinfection system. Infect Control Hosp Epidemiol 2018;39:1250-3

146. Bache SE, Maclean M, Gettinby G, Anderson JG, MacGregor SJ, Taggart I. Universal decontamination of hospital surfaces in an occupied inpatient room with a continuous $405 \mathrm{~nm}$ light source. J Hosp Infect 2018;98:67-73.

147. Tamimi AH, Carlino S, Gerba CP. Long-term efficacy of a self-disinfecting coating in an intensive care unit. Am J Infect Control 2014;42:1178-81.

148. Rutala WA, Weber DJ. New disinfection and sterilization methods. Emerg Infect Dis 2001;7:348-53.

149. Rutala WA, White MS, Gergen MF, Weber DJ. Bacterial contamination of keyboards: efficacy and functional impact of disinfectants. Infect Control Hosp Epidemiol 2006;27:372-7.

150. Fitton K, Barber K, Karamon A, Zuehlke N, Atwell S, Enright S. Long acting waterstable organosilane and its sustained effect on reducing microbial load in the intensive care unit. Am J Infect Control 2017;45:23.

151. Weber DJ, Rutala WA. Self-disinfecting surfaces: review of current methodologies and future prospects. Am J Infect Control 2013;41:31-5. 